\title{
Innovative Pedagogical Methodologies: Self Learning Experience - SeLE
}

\author{
Veronica Barbosa ${ }^{1}$, Isabelle de Oliveira ${ }^{2}$, Joyce de Oliveira ${ }^{3}$, Júlio de Albuquerque ${ }^{4}$, Naslley Bernardes ${ }^{1}$, \\ Juliano da Silva ${ }^{5,6}$, Enio Costa ${ }^{7}$ and Gentil Luiz II ${ }^{* 8}$ \\ ${ }^{1}$ Faculdade de Letras, Universidade Federal de Alagoas \\ (Maceió, Brazil) \\ Email: tina.cbs [AT] gmail.com \\ ${ }^{2}$ Instituto Federal de Alagoas \\ (Murici, Brazil) \\ Email: isabellelouse35 [AT] hotmail.com \\ ${ }^{3}$ Instituto Federal de Alagoas \\ (Murici, Brazil) \\ Email: mariajoyce1.jm [AT] gmail.com \\ ${ }^{4}$ Postgraduate Program in Information Science, Universidade Federal de Alagoas \\ (Maceió, Brazil) \\ Email: julioenders [AT] outlook.com \\ ${ }^{5}$ Postgraduate Program in Chemistry and Biotechnology, Instituto de Química e Biotecnologia, Universidade Federal de Alagoas \\ (Maceió, Brazil) \\ Email: julianobuenoufal [AT] gmail.com \\ ${ }^{6}$ Instituto Federal de Alagoas \\ (Viçosa, Brazil) \\ Email: juliano.silva [AT] ifal.edu.br \\ ${ }^{7}$ Instituto Federal do Ceará \\ (Fortaleza, Brazil) \\ Email: prof.eniocosta [AT] gmail.com \\ ${ }^{8}$ Instituto Federal de Alagoas \\ (Marechal Deodoro, Brazil) \\ *Corresponding author's email: gentil.luiz [AT] ifal.edu.br
}

\begin{abstract}
Regarding contemporary formal education, several students question themselves about specific information treated in the classroom. In Brazil, courses focusing on building knowledge for undergraduate purposes are like undergraduate degrees. The various existing Brazilian undergraduate degrees undergo in their curriculum notes various changes for the most different motivations. Especially in a world where knowledge is rapidly reconstructed and shaped with the emergence of new technologies in the new post-digital age. These circumstances create difficulties due to the need for constant legislative updating.
\end{abstract}

In this context, the teacher finds an extremely unstable situation, the point of view of its implementation, where, on the one hand, has the need for constant changes and technological adaptations, and other guiding legislation of their work with updating needs.

The indiscriminate use of technology makes mostly people without initiatives to build creative thinking. In addition, there are daily cases of depression and various diseases arising from the occurrence of this fast-paced, connected and globalized world. From this point of view, it is up to the teacher to broker an orientation for to the use of such innovations to be beneficial, not the other way around. In this paper, we present one of the possible uses of technology, inserting or learning as a protagonist of its own educational process and presenting very interesting results of engagement.

Keywords - Innovation, Self Learning, Pedagogical Methodologies 


\section{INTRODUCTION}

In the process of knowledge construction, 'the risk of error and illusion must be taken into account' [1]. Thinking about the future of the learning process then implies minimizing these risks, not underestimating the problem of error and illusion. Knowledge in its various forms is the result of a translation or reconstruction done through language and thought and is therefore subject to error. The education of the future must follow a path to show that there is no knowledge that to some degree is not threatened by error or delusion, but that it can always be minimized.

The development of scientific knowledge is an important tool in the detection of errors and in the fight against illusions imposed by the phenomenological perception of scholars. However, the paradigms on which science is based may still present these risks, so it is clear that no scientific theory is forever immune from error.

In this context many scholars propose various approaches in order to lessen the implications of errors. For example, 'teaching by research' [2-3]. Practical investigative activities require intense student participation during its execution. This practice differs from others because 'it necessarily involves discussion of ideas, hypothesis making and experimentation for testing' [2] whatever the area of knowledge in question. The student should act, through physical experience, in the development of the activity or through observation of the teacher in a demonstration, provided that 'the activity presents itself as a material object' [4]. This type of activity stimulates intellectual, physical and social activity to the fullest. Contributing significantly in the internalization of the studied concepts.

It is observed the contemporary era is 'marked by the information society' [5]. Thus, the use of technologies in education is another aspect of future learning. Thus the teaching-learning process tends to be permanent, diffuse, often non-formal, such as lifelong learning (which consists in the idea of the educational contribution provided by adults. It is also used for better understanding the idea that learning occurs in everywhere and at the moment), and more focused on the learners themselves, involving more active modes of learning focused on mastery of skills and competences than on single content absorption. However, simply inserting technology into schools will not have a greater impact on the education of those who attend them and will not prepare them for the information society. That would only mean trying to walk faster, but in the wrong direction.

The educational model must be rethought to reverse the direction in which education moves. Instead of an education thought of as content-teaching-teacher, we need future-process-learning-student-based education.

\section{E-LEARNING}

With the great advances of technology in recent decades, a new form of learning has emerged in recent years. Increasingly present, the use of the Internet, whether through online platforms or even autonomously, has become an important tool in the dissemination of knowledge, connecting people, promoting access to information in ways never seen before in the entire history of humanity. thus promoting a rich exchange of information and knowledge.

The availability of study materials becomes more efficient as teachers can distribute materials with different ways of reaching, and the student can use the one that conveys the knowledge more accurately for their conditions and way of learning. It is also possible to use more varied teaching techniques, using audios, videos, specific reminders, images and other devices.

Another great advantage of using the internet in the learning process is the permanent or almost permanent availability of the educational collection, being at the discretion of the student what is the most appropriate time for their studies, maximizing their learning and avoiding wasted time with displacement, for example, and thus increasing its yield.

These advantages also consequently directly influence one of the student's biggest learning devices: 'motivation' [7]. Full availability and access to educational content motivates the student to learn. No longer becoming obsolete at the time and place of class, as well as a more restricted form of teaching. Online access to content enables students to access and study at their peak hours, which optimizes their learning and encourages them to pursue even more knowledge, creating an upward spiral of student learning.

\section{SELF-TAUGHT}

With technological development, self-taught trends are progressing more and more. Thus, this concept is characterized by the tendency in which the individual develops intellectually independently and autonomously, regardless of the existence of a teacher or mentor, i.e., is a tendency for the development of new knowledge. 
Thus, the development of such ability can bring innumerable advantages for the human being, such as: inducing personal independence; provide greater efficiency; stimulate creativity; develop their potential; generate professional versatility; promote competitive advantage; among others. These qualities show great importance in differentiation processes in the competition of individuals with higher and lower qualifications.

Given this, the human skills related to cunning, communication, insight, creativity, learning ability (self-taught) and reliability are of great relevance, since 'competitive intelligence professionals must interact with those responsible for decision making' 8. Therefore, it is an important quality for the requirements to stand out and excel.

\section{MAKING ONLINE BUSINESS}

The internet has become the most fascinating and technological communication tool in the era of dialogue. For [9], 'the rapid growth of technology has provided man with greater capacity for analysis, calculation, organization, storage and dissemination of information'. However, there is a more important factor that attracts man's relationship with technological modernity: the alternative that the individual has to communicate in a network and produce a virtual space.

In addition to being able to exploit the resources of the internet as a means of storing information, it is also a means of promoting products, services and brands. In the age of modernity, Digital Marketing is a powerful new tool for companies that are experiencing the moment of competitiveness. This contemporary trend makes the consumer, out of curiosity to observe the creativities of advertisements, be interested in looking for the company's products, instead of having the disclosure of "door-to-door".

Online services offer advantages to consumers and marketers. These offer a better personal customer relationship, as when purchasing and negotiating the product consumers will not have to deal with sellers, and will have all the time they need to think about what they really want. Online stores will have lower costs, thus increasing their production.

\section{METHODOLOGY}

The project proposal was presented to the students of the Federal Institute of Alagoas - Campus Murici, during high school physics classes. The Self Learning Experience (SeLE) project consisted of weekly meeting with groups of students who would like to gain some specific knowledge in areas other than those addressed in the classroom in the usual high school curriculum components. Guided by a specific mentor, groups with common interests would use the information freely available online to achieve a year-round end goal.

In total, 3 teams accepted the project perspectives and decided on the following themes:

Team 1: Independent French Learning - Aim to acquire reading habit and increase vocabulary of another language;

Team 2: StartUp - Gourmet Sweets - Objective of creating a Gourmet Sweets StartUp Online;

Team 3: Personal Administration - Objective of organizing personal finances.

\section{RESULTS AND DISCUSSION}

\subsection{Expanding knowledge in the French language}

School language teachers were consulted for approval of our method of self-learning in the French language. In this group, the method defined was simple: we chose books in French and advised that the students involved should expand their vocabulary in the language through the use of dictionaries during each reading. Over the course of six months, the aim was for the students to potentially increase their reading ability in the French language, although there was a grammatical deficiency, it was possible to read books in the French language without the help of dictionaries. The goal would be to achieve the level of communication applied to each student's future projects involving the language. In this group there was low engagement, making the result unreachable.

\subsection{Making the first StartUp at the school}

In the group StartUp - Candy Gourmet, after several meetings we decided that the product to be produced and marketed via social networks would be the brigadeiro made of fruit waste. Banana peel brigadeiro and lemon peel zest were examples we tried to produce. This team, in turn, managed to produce their first MVP (minimum viable product) however after the start of production, the team ended up diverging in some interesting items that improved the business management learning for the participants of this team. This group realized that the lack of alignment of mindset with the divergent goal of profit and customer satisfaction led to many conflicts. It was also noted that the lack of agreement on 
the chances of resignation and leadership within the team presented itself as a very strong point for StartUp's failure. The group had many members with strong leadership characteristics, which made the internal management of the business unfeasible.

\subsection{Domestic economy for to life}

The last group, Personal Administration, formed by only three people, was able to achieve the goal: Create a monthly financial reserve and pay off all debts by acquiring financial education. This group learned concepts of home economics, financial education, spreadsheet design, product pricing, and entrepreneurship. In this group, two curious cases emerged: One of the members had a small production of artisan truffles, and the other wanted to undertake in the food field, but had no idea how to start. Analyzing these two possibilities, we realized that we could do two jobs:1) Reformulate the artisan truffle business; 2) Create a new local food business.

\subsection{Reformulate the artisan truffle business}

The reformulation process basically consisted of adding value to the existing product and expanding sales channels. For this, we studied the product that initially did not have an inviting presentation to purchase. The truffles were sold without any associated brand or proper packaging.

After the diagnosis (with canvas and 5W2H tools), we created the brand @ trufasdabia_ (along with Instagram) and made a suitable packaging for the product.

With the redesigned product, the truffle revenue increased by $600 \%$ making a difference at the close of each month, just with digital marketing work and business mentoring.

\subsection{Create a new local food business}

To enable the creation of a new business in the gastronomic field, there was research in stages:

Step 1 - Data collection about the food business in the city of Murici-AL. That is, we needed to know what products were traded;

Step 2 - Decide the product. After analysis, we decided to make brownie of various flavors, which consists of a specific type of cake with internal filling. Something like a "sweet stuffed cake sandwich";

Step 3 - Brand Creation. We work to create a brand associated with the seller's name. From there came @jmbrownie with instagram sales and market positioning strategy plan;

Step 4 - Production Standardization. We developed a POP - Standard Operating Procedure for the manufacture of brownies;

Step 5 - Distribution. We chose strategic points of sales and distribution through salespeople working via commission (percentage of sales);

Step 6 - Disclosure via entrepreneurship events;

Currently, sales of @jmbrownie_complement much of family income and are sold in 5 different cities, and have reached several points in Brazil. Realizing a successful case within the perspectives of the SeLE project.

The internet has become the most fascinating and technological communication tool in the era of dialogue. For Escobar et al (1994), 'the rapid growth of technology has provided man with greater capacity for analysis, calculation, organization, storage and dissemination of information'. However, there is a more important factor that attracts man's relationship with technological modernity: the alternative that the individual has to communicate in a network and produce a virtual space.

In addition to being able to exploit the resources of the internet as a means of storing information, it is also a means of promoting products, services and brands. In the age of modernity, Digital Marketing is a powerful new tool for companies that are experiencing the moment of competitiveness. This contemporary trend makes the consumer, out of curiosity to observe the creativities of advertisements, be interested in looking for the company's products, instead of having the disclosure of "door-to-door".

Online services offer advantages to consumers and marketers. These offer a better personal customer relationship, as when purchasing and negotiating the product consumers will not have to deal with sellers, and will have all the time they need to think about what they really want. Online stores will have lower costs, thus increasing their production.

\section{ACKNOWLEDGEMENT}

It is possible to understand, after the aforementioned discussions, that the SeLE Project applied to the Federal Institute of Alagoas - Murici campus, was successful, since it succeeded through a differentiated education, in which the student became the protagonist agent of the process. educational, transform the lives of participants, both in the aspect of the 
teaching-learning posture in formal education, as well as in personal and financial aspects. Thus proving that this kind of transformative education is worth its application.

\section{REFERENCES}

[1] Morin, E. (2002). Seven complex lessons in education for the future. Unesco.

[2] Munford, D., \& Lima, M. E. C. D. C. (2007). Ensinar ciências por investigação: em quê estamos de acordo?. Ensaio Pesquisa em Educação em Ciências (Belo Horizonte), 9(1), 89-111.

[3] Zômpero, A. F., \& Laburú, C. E. (2011). Atividades investigativas no ensino de ciências: aspectos históricos e diferentes abordagens. Ensaio Pesquisa em Educação em Ciências (Belo Horizonte), 13(3), 67-80.

[4] Andrade, M. L. F. D., \& Massabni, V. G. (2011). O desenvolvimento de atividades práticas na escola: um desafio para os professores de ciências. Ciência \& Educação (Bauru), 17(4), 835-854.

[5] Toffler, A., \& Alvin, T. (1980). The third wave (Vol. 484). New York: Bantam books.

[6] Silva, P. N. M. D. (2011). A Influência do Digital na Criação de Espaços de Aprendizagem de Alta Qualidade: o Espaço Como Agente de Mudança.

[7] Holanda, V. R. D., Pinheiro, A. K. B., \& Pagliuca, L. M. F. (2013). Aprendizagem na educação online: análise de conceito. Revista Brasileira de Enfermagem, 66(3), 406-411.

[8] Oliveira, P., \& Lacerda, J. (2007). Habilidades e competências desejáveis aos profissionais de inteligência competitiva. Ciência da informação, 36(2), 46-53.

[9] Escobar, A., Hess, D., Licha, I., Sibley, W., Strathern, M., \& Sutz, J. (1994). Welcome to Cyberia: Notes on the Anthropology of Cyberculture [and comments and reply]. Current anthropology, 35(3), 211-231. 